\title{
The Effect of the Scientific Approach on Enhancing Elementary School Students' Learning Outcomes in Indonesia: A Meta-Analysis
}

\author{
Anggit Grahito Wicaksono \\ Elementary Teacher Education \\ Universitas Slamet Riyadi \\ Surakarta, Indonesia
}

\author{
Ratna Widyaningrum* \\ Elementary Teacher Education \\ Universitas Slamet Riyadi \\ Surakarta, Indonesia \\ ratnawidya133@gmail.com
}

\author{
J Jumanto \\ Elementary Teacher Education \\ Universitas Slamet Riyadi \\ Surakarta, Indonesia
}

\author{
Ema Butsi Prihastari \\ Elementary Teacher Education \\ Universitas Slamet Riyadi \\ Surakarta, Indonesia
}

\author{
Ani Restuningsih \\ Elementary Teacher Education \\ Universitas Slamet Riyadi \\ Surakarta, Indonesia
}

\begin{abstract}
The 2013 curriculum provides a conception that the scientific approach to learning includes observing, asking, reasoning, creating, communicating. The scientific approach is appropriate for science because it is a student-centered learning approach and the learning process conforms to scientific criteria. This study aimed to investigate the effect size of the scientific approach on improving the science learning outcomes of Indonesian elementary school students. This study uses metaanalysis data in the form of descriptive exploratory quantitative. This study uses data collected in the form of journal articles, theses, and publication texts that are sought from the "Indonesia Onesearch" portal. Data analysis was performed by calculating the effect size of the same findings for similar problems. Results of tracing scientific publications obtained 20 documents published between 2013-2018 based on certain criteria. The results of this study indicated that the average effect size of the scientific approach to improving science learning outcomes of elementary school students is 1.1, including in the high category. The result of the effect size value shows that the scientific approach contributes $84 \%-88 \%$ to the improvement of science learning outcomes of Indonesian elementary school students. The implication of this research lies in the development of a scientific approach to various changes in the elementary school learning process following the mandate of the 2013 curriculum.
\end{abstract}

Keywords- Meta-Analysis, Scientific Approach, Science Learning Outcomes

\section{INTRODUCTION}

The problems that are quite concerning from education in Indonesia especially in the field of Natural Sciences can be seen from the results of the TIMSS (Trends in Student Achievement in Mathematics and Science) survey. TIMSS is a study that is carried out every four years, namely in 1995 , 1999, 2003, 2007, 2011, and so on [1], [2]. Indonesia is at the bottom of the list compared to several countries in Asia. The average science achievement score of Indonesian students in TIMSS 1999, 2003, 2007, 2011, and 2015 was 435, 420, 427, 406, and 397 respectively [3]. These scores provide information that Indonesian students were ranked 32 out of 38 countries in 1999, ranked 35 out of 46 countries in 2003, ranking 35 out of 49 countries in 2007, ranking 39 out of 42 countries in 2011, and ranking 45 out of 48 countries in 2015 [4], [5]. Meanwhile, in the field of education research by the OECD in the 2009 International Student Assessment (PISA) study program, it showed that Indonesia was able to count, read and science education was ranked 60 out of 65 countries, but in 2012 it fell to rank 64 [6], [7]. The results of the two surveys show that Indonesia has experienced a significant decrease in Human Resources, especially in the field of science education.

Related to the dimensions of science as a product and process, learning should be taught to students how this knowledge is found by students [8]. There are still many teachers who do not have adequate knowledge and skills in selecting and implementing various learning methods and approaches that can increase curiosity, activeness, interest, and motivation [9], [10]. The teacher must choose a learning approach that is by the characteristics of the student so that it can affect students' science learning outcomes. A suitable approach used to increase student activity in the learning process is a student-oriented approach. One approach that can develop the teacher's role as a facilitator and guide for developing students' potential is to use a scientific approach.

The 2013 curriculum provides a conception that the scientific approach in learning includes learning: observing, asking, reasoning, trying/creating, presenting/communicating [11], [12]. This scientific approach is appropriate for use in science subjects because it is a student-centered learning approach and at the same time the learning process meets scientific criteria. Stating that the scientific approach, calls the scientific learning process model is learning based on a scientific approach oriented toward fostering students' ability to solve problems through a series of inquiry activities that demand critical thinking skills, creative thinking, and communication to improve abilities and student knowledge 
[13], [14]. The characteristics of the scientific approach according are objective, factual, systematic, meticulous, and precise method, logical, actual, disinterested (impartial learning), unsupported opinion (does not foster an opinion or opinion that is not accompanied by real evidence), and verification. Besides having characteristics, there are also learning objectives with a scientific approach [15], [16]. Some of the learning objectives with a scientific approach are (1) increasing intellectual ability, especially thinking skills in high-level students, (2) forming students' abilities to solve the problem systematically, (3) creating learning conditions where students feel that learning is a form of learning needs, (4) obtained high learning outcomes, (5) train students in communicating ideas especially in writing scientific articles, (6) develop student character [17], [18].

A scientific approach is a basic approach in the 2013 curriculum. Learning activities in the 2013 curriculum for all levels are carried out using a scientific approach. The scientific approach is believed to be a golden bridge for the development of students' attitudes, skills, and knowledge. The implementation of the 2013 curriculum in addition to using a scientific approach, another characteristic of 2013 curriculum is that there is a change in the content or teaching material components. Subjects are presented thematically or integrated. One of the subject's contents in the curriculum structure in elementary is Natural Sciences. Science is a group of knowledge that has special characteristics that study natural phenomena that are factual in the form of reality or events, and the cause and effect relationship [19], [20]. Research on the effect of applying the scientific approach to student science learning outcomes in elementary schools has been widely conducted and it turns out the results reveal that the scientific approach can improve student learning outcomes in science elementary schools.

Based on observations and tracing of scientific publications conducted through the "Indonesia Onesearch" portal, 53 studies have been found on these published between 2013-2018. All of these studies are still very poor in readability, even though the results of these studies can be used by teachers, students, parents, students, researchers, and various interested parties to obtain various information. The information obtained includes improving the quality of learning outcomes, the quality of learners, textbooks, teaching materials, and can determine the steps and actions needed in further research or just as a means of adding insight and knowledge.

Most researchers find it difficult to follow the rapid development of research results published through online journals or repositories. The researchers highly depend on the summary of the available research results. There are two methods developed to summarize research, namely the metaanalysis method and the meta-ethnographic method. Research on the effect of the scientific approach on improving science learning outcomes of elementary school students has been widely carried out, so it is necessary to conduct a metaanalysis to get a unified understanding or general conclusions from a similar study. The urgency of this research is to get the same understanding or general conclusions from similar research and can be used as a result of preliminary research in further research on scientific approaches in science learning. So this meta-analysis was carried out to investigate the effect size of the scientific approach on improving the science learning outcomes of Indonesian elementary school students. The implication of this research is to develop a scientific approach for various changes in the elementary school learning process following the requirements of the 2013 curriculum.

\section{METHODS}

This type of research is a meta-analysis. A meta-analysis method is a form of a quantitative summary that examines the results of research statistically. Meanwhile, the metaethnographic method is a form of qualitative summary. The meta-analysis method is considered more objective (focusing on available data) so that the results obtained are more accurate and credible [21]. The meta-analysis states the results of the study using effect size (ES). Effect Size (ES) indicates the extent to which a variable affects other variables in a study or shows how effectively a variable influence other variable. The basic aim of the meta-analysis is to provide methodological similarities with the literature review needed from an experimental study [22], [23].

Meta-analysis is conducted by summarizing research data, reviewing and analysing research data from several existing research results. This study uses data collected in the form of journal articles, theses, and publication texts that are sought from the Indonesia One Search (IOS) portal. Data collected from the "Indonesia One Search portal (IOS)" is limited between 2013-2018 and with the keywords "Pengaruh Pendekatan Saintifik" which means effects of scientific approaches and "Hasil Belajar IPA di Sekolah Dasar" which means science learning outcome in elementary school obtained a small population of 53 scientific publications in the form of journal articles and scientific publication others. Subsequently selected so that a sample of 20 scientific publications are selected that meet the criteria, namely: (1) the results can state the effect size of the approach used has an impact on students' science learning outcomes in elementary schools; (2) several scientific publications that have been found were not selected because they did not mention or describe in full the quantitative descriptive manner so that the vaccine effect value could not be calculated.

The data analysis techniques for calculating effect size uses the statistical formula presented by [24], which can be seen in Table I.

TABLE I. EFFECT SIZE Formulas

\begin{tabular}{|l|l|}
\hline Given Statistical Data & Formulas \\
\hline Average and standard deviation in one group & $E S=\frac{\bar{x}_{\text {post }}-\bar{x}_{\text {pre }}}{S D_{\text {pre }}}$ \\
\hline Average and standard deviation in each group (two groups only posttest) & $E S=\frac{\bar{x}_{\text {experiment }}-\bar{x}_{\text {control }}}{S D_{\text {control }}}$ \\
\hline
\end{tabular}




\begin{tabular}{|l|l|}
\hline Given Statistical Data & Formulas \\
\hline The mean and standard deviation of each group (two groups were pre-posttest) & $E S=\frac{\left(\bar{x}_{\text {post }}-\bar{x}_{\text {pre }}\right)_{\text {experiment }}-\left(\bar{x}_{\text {post }}-\bar{x}_{\text {pre }}\right)_{\text {control }}}{\left(\frac{S D_{\text {precontrol }}+S D_{\text {pre experiment }}+S D_{\text {post control }}}{3}\right)}$ \\
\hline $\mathrm{t}$ value & $E S=t \sqrt{\frac{1}{n_{\text {exp riment }}}+\frac{1}{n_{\text {control }}}}$ \\
\hline
\end{tabular}

The results of the effect size values can then be interpreted into the high, medium, and low categories using the categories presented by [25], these categories can be seen in Table II.
The results of the effect size obtained can be interpreted to determine how much influence the independent variable has on the dependent variable with the conditions shown in Table III [26].

TABLE II. CATEGORY EFFECT Size INTERPRETATION

\begin{tabular}{|c|c|}
\hline Effect Size (ES) & Standard Cohen's Category \\
\hline $0 \leq E S \leq 0,2$ & Low \\
\hline $0,2 \leq E S \leq 0,8$ & Medium \\
\hline$E S \geq 0,8$ & High \\
\hline
\end{tabular}

TABLE III. INTERPRETATION OF EFFECT SIZE (ES) EFFECT OF INDEPENDENT ON DEPENDENT VARIABLES

\begin{tabular}{|l|l|l|l|l|l|l|l|l|l|l|l|l|l|l|l|l|l|l|}
\hline ES & 0,0 & 0,1 & 0,2 & 0,3 & 0,4 & 0,5 & 0,6 & 0,7 & 0,8 & 0,9 & 1,0 & 1,2 & 1,4 & 1,6 & 1,8 & 2,0 & 2,5 & 3,0 \\
\hline $\begin{array}{l}\text { Effect } \\
(\%)\end{array}$ & 50 & 54 & 58 & 62 & 66 & 69 & 73 & 76 & 79 & 82 & 84 & 88 & 92 & 95 & 96 & 98 & 99 & 99,9 \\
\hline
\end{tabular}

\section{RESULT AND DISCUSSION}

In this study, the number of scientific publications in the form of articles and publication manuscripts following the research objective was 20 scientific publications. The details and calculation of the effect size are carried out to determine the effect of the scientific approach to the improvement of science learning outcomes of students in elementary schools shown in Table IV.

TABLE IV. Detalls And CATEgory EFfect Size of Scientific Publications

\begin{tabular}{|c|c|c|c|c|c|c|}
\hline Author/Year & $\begin{array}{l}\text { Research } \\
\text { Design }\end{array}$ & $\bar{x}_{\text {exp eriment }}$ & $\bar{x}_{\text {control }}$ & $S D_{\text {control }}$ & ES & Category \\
\hline $\begin{array}{lrr}\mathrm{Ni} \quad \text { Made } & \text { Eny } \\
\text { Rismayanti, Ni } & \text { Wayan } \\
\text { Arini, dan } & \text { Made } \\
\text { Sumantri/2015 } & \end{array}$ & $\begin{array}{l}\text { Posttest-Only } \\
\text { Control } \\
\text { Group Design }\end{array}$ & 18,67 & 14,08 & 2,92 & 1,6 & High \\
\hline Rahmani/2016 & $\begin{array}{l}\text { One Group } \\
\text { Pretest-Posttest } \\
\text { Design }\end{array}$ & $\bar{x}_{\text {post }}=83,07$ & $\bar{x}_{\text {pre }}=73,77$ & $S D_{\text {pre }}=5,72$ & 1,6 & High \\
\hline $\begin{array}{l}\text { Derry } \\
\text { Hargiyantoro/2014 }\end{array}$ & $\begin{array}{l}\text { Pretest-Posttest } \\
\text { Control Group } \\
\text { Design }\end{array}$ & $\begin{array}{l}\bar{x}_{\text {pre }}=41,13 \\
\bar{x}_{\text {post }}=47,72\end{array}$ & $\begin{array}{l}\bar{x}_{\text {pre }}=52,14 \\
\bar{x}_{\text {post }}=48,85\end{array}$ & $\begin{array}{l}S D_{\text {pre }}=10,89 \\
S D_{\text {post }}=11,11 \\
S D_{\text {pre (Exp })}=13,71\end{array}$ & 0,8 & Medium \\
\hline $\begin{array}{lrl}\begin{array}{l}\text { Lastian Dwi } \\
\text { dan }\end{array} & \text { Hastuti } \\
\text { Renyaan/2017 } & \text { Veator } \\
\end{array}$ & $\begin{array}{l}\text { Posttest-Only } \\
\text { Control } \\
\text { Group Design } \\
\end{array}$ & 18,063 & 14,563 & 5,61 & 0,6 & Medium \\
\hline $\begin{array}{l}\text { Ni Wayan Putri } \\
\text { Yuliana, I Wayan } \\
\text { Rinda Suardika, dan I } \\
\text { Ketut Ardana/2015 } \\
\end{array}$ & $\begin{array}{l}\text { Non-equivalent } \\
\text { Control Group } \\
\text { Design }\end{array}$ & 77,16 & 70,45 & 8,23 & 0,8 & Medium \\
\hline $\begin{array}{lr}\text { I Made Adi Arnawa, I } \\
\text { Wayan Rinda Suardika, } \\
\text { dan I } & \text { Ketut } \\
\text { Ardana/2015 } & \\
\end{array}$ & $\begin{array}{l}\text { Randomized } \\
\text { Control-Group } \\
\text { Pretest-Posttest } \\
\text { Design } \\
\end{array}$ & 75,80 & 66,50 & 11,96 & 0,8 & Medium \\
\hline $\begin{array}{l}\text { Komang Ayu Tri Astiti, } \\
\text { I Wayan Rinda } \\
\text { Suardika, dan I } \\
\text { Ardana/2015 } \\
\end{array}$ & $\begin{array}{l}\text { Randomized } \\
\text { Control-Group } \\
\text { Pretest-Posttest } \\
\text { Design } \\
\end{array}$ & 82,08 & 71,56 & 9,15 & 1,1 & High \\
\hline $\begin{array}{l}\text { Ketut Restana Arta, } \\
\text { Anak Agung Gede } \\
\text { Agung, dan I Wayan } \\
\text { Widiana/2015 }\end{array}$ & $\begin{array}{l}\text { Non-equivalent } \\
\text { Control Group } \\
\text { Design }\end{array}$ & 21,3 & 14,7 & 3,35 & 2,0 & High \\
\hline
\end{tabular}




\begin{tabular}{|c|c|c|c|c|c|c|}
\hline $\begin{array}{lr}\text { Ni Luh Putu Tiyani, I } \\
\text { Wayan Rinda Suardika, } \\
\text { dan I } r \text { Ketut } \\
\text { Ardana/2015 }\end{array}$ & $\begin{array}{l}\text { Non-equivalent } \\
\text { Control Group } \\
\text { Design }\end{array}$ & 74,05 & $\begin{array}{l}70,38 \\
\end{array}$ & 14,76 & 0,2 & Medium \\
\hline \begin{tabular}{lr}
\multicolumn{2}{l}{ Ni Luh Eka Sawitri, I } \\
Wayan Rinda Suardika, \\
dan I $r$ \\
Ardana/2015
\end{tabular} & $\begin{array}{l}\text { Non-equivalent } \\
\text { Control Group } \\
\text { Design }\end{array}$ & 72,30 & 58,32 & 16,75 & 0,8 & Medium \\
\hline $\begin{array}{l}\text { Putu Desi Ratnasari, } \\
\text { Anak Agung Gede } \\
\text { Agung, dan I Wayan } \\
\text { Widiana/2015 }\end{array}$ & $\begin{array}{lr}\text { The } & \text { Posttest- } \\
\text { Only } & \text { Control } \\
\text { Group } & \end{array}$ & 24.9 & 22.8 & 4.2 & 0,5 & Medium \\
\hline $\begin{array}{ll}\text { Praba } & \text { Wahyu } \\
\text { Hidayat/2015 } & \end{array}$ & $\begin{array}{l}\text { One Group } \\
\text { Pretest-Posttest } \\
\text { Design }\end{array}$ & $\begin{array}{l}\text { tvalue }=4,75 \\
\mathrm{ne}=32 \\
\mathrm{nc}=32\end{array}$ & & & 1,2 & High \\
\hline $\begin{array}{ll}\text { Elgita } & \text { Herviani } \\
\text { Munggaran/2018 }\end{array}$ & $\begin{array}{l}\text { Pretest-Posttest } \\
\text { Control Group } \\
\text { Design }\end{array}$ & $\begin{array}{l}\text { tvalue }=3,12 \\
\text { ne }=27 \\
\text { nc }=24\end{array}$ & & & 0,9 & High \\
\hline 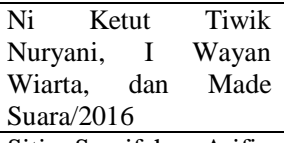 & $\begin{array}{l}\text { Non-equivalen } \\
\text { Control Group } \\
\text { Design }\end{array}$ & $\begin{array}{l}\text { tvalue }=4,18 \\
\text { ne }=39 \\
\text { nc }=38\end{array}$ & & & 1,0 & High \\
\hline $\begin{array}{ll}\text { Siti Syarifah, } & \text { Arifin } \\
\text { Ahmad, dan } & \text { Andi } \\
\text { Cudai Nur/2016 } & \end{array}$ & $\begin{array}{l}\text { Non Ekuivalen } \\
\text { Pretest-Posttest } \\
\text { Design }\end{array}$ & $\begin{array}{l}\bar{x}_{\text {pre }}=53,69 \\
\bar{x}_{\text {post }}=71,74\end{array}$ & $\begin{array}{l}\bar{x}_{\text {pre }}=53,48 \\
\bar{x}_{\text {post }}=60\end{array}$ & $\begin{array}{l}S D_{\text {pre }}=6,48 \\
S D_{\text {post }}=8,65 \\
S D_{\text {pre(Exp) }}=10,3\end{array}$ & 1,4 & High \\
\hline $\begin{array}{l}\text { Ni Kadek Tariani, Ni } \\
\text { Ketut Suarni, dan I } \\
\text { Gede Astawan/2015 }\end{array}$ & $\begin{array}{l}\text { One Group } \\
\text { Pretest-Posttest } \\
\text { Design }\end{array}$ & $\bar{x}_{\text {post }}=72,11$ & $\bar{x}_{\text {pre }}=50,22$ & $S D_{\text {pre }}=15,49$ & 1,4 & High \\
\hline $\begin{array}{lr}\text { Komang } & \text { Trisna } \\
\text { Mahartini, Ni } & \text { Ketut } \\
\text { Suarni, dan I } & \text { Gede } \\
\text { Astawan/2015 } & \\
\end{array}$ & $\begin{array}{l}\text { One Group } \\
\text { Pretest Posttest } \\
\text { Design }\end{array}$ & $\bar{x}_{\text {post }}=72,98$ & $\bar{x}_{\text {pre }}=46,55$ & $S D_{\text {pre }}=11,09$ & 2,4 & High \\
\hline Siti Maskanah/2015 & $\begin{array}{lr}\text { The } & \text { Posttest } \\
\text { Only } & \text { Control } \\
\text { Group Design }\end{array}$ & 64,25 & 58,45 & 12,16 & 0,5 & Medium \\
\hline $\begin{array}{l}\text { Muhammad } \\
\text { Asrofi/2016 }\end{array}$ & $\begin{array}{l}\text { One Group } \\
\text { Pretest Posttest } \\
\text { Design }\end{array}$ & $\begin{array}{l}\text { tvalue }=5,59 \\
\mathrm{ne}=28 \\
\mathrm{nc}=28\end{array}$ & & & 1,5 & High \\
\hline Raihan Fannesa/2018 & $\begin{array}{l}\text { Non-equivalent } \\
\text { Pretest-Posttest } \\
\text { Control Group } \\
\end{array}$ & 79 & 69,142 & 14,005 & 0,7 & Medium \\
\hline \multicolumn{5}{|l|}{$\begin{array}{l}\sum \text { Effect Size (ES) } \\
\text { Average Effect Size (ES) } \\
\text { Maximum Effect Size (ES) } \\
\text { Minimum Effect Size (ES) } \\
\text { Standard Deviation (SD) }\end{array}$} & \multicolumn{2}{|c|}{$\begin{array}{l}21,8 \\
1,1 \\
2,4 \\
0,2 \\
0,537\end{array}$} \\
\hline
\end{tabular}

From table IV it can be seen that the results of the calculation of effect size prices obtained the highest effect size is 2.4 categorized in the high category so that shows that the scientific approach influences $98 \%$ - 99\% on the science learning achievement of elementary schools' students and the lowest effect size is 0,2 is categorized as low so it shows that the scientific approach has an effect of only $58 \%$ on the learning outcomes of science students in elementary schools. Meanwhile, the average effect size of $1.1(\mathrm{SD}=0.537)$ is categorized as high. These results show that the effect of the scientific approach can improve student science learning outcomes in elementary schools by $84 \%-88 \%$ (can be seen in Table III). The results of the distribution of effect sizes based on their categories can be illustrated in the pie chart in Figure 1.

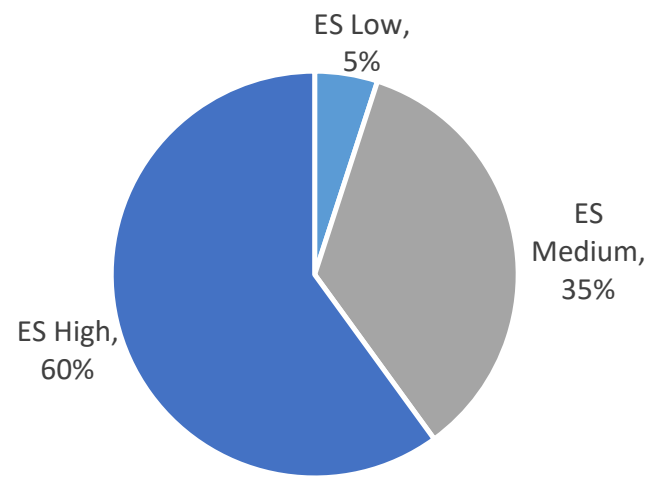

Fig. 1. Distribution of Effect Size (ES) Categories

Based on Figure 1 shows that the effect size of scientific publications about the effect of the scientific approach to the 
improvement of science learning outcomes of students in elementary schools which are included in the low category is only $5 \%$, including the moderate category $35 \%$, and those included in the high category $60 \%$.

This illustrates in Figure 1. shows that the scientific approach has a high influence on student learning outcomes in elementary school. This can occur because the Scientific approach is learning that encourages children to carry out the following scientific skills: observing; ask; gathering information; associate; and communicating [19], [27]. In the scientific approach to the learning process, the teacher provides direct experience, and students are allowed to be active in learning activities where students can use their minds to build understanding. All activities in a scientific approach stimulate students to be active, both physically and mentally. This makes students not only learning objects but learning subjects. The application of the Scientific Approach in science learning makes students enthusiastic in learning because the method can provide opportunities for students to better understand what the goals of problems exist in learning and provide more understanding to students to solve the problems presented through gradual guidance. This was also stated by Vygotsky [28], [29] that the purpose of the scientific approach is to improve intellectual ability, especially thinking skill in high-level students, to shape the ability of students to solve a problem systematically, creating learning conditions where students feel that learning is a necessity, obtain high learning outcomes, to train students in communicating ideas, especially in writing scientific articles and to develop student character. Science education based on science process skills enhances students' scientific problem-solving skills, supports curiosity because it provides direct learning, improves the quality of education as it develops questioning and reasoning skills of the students [30], [31]. Other constructivist learning methods, such as problem-based learning, inquiry-based learning, process-oriented guided-inquiry learning, project-based learning, research-based learning, or other methods that have the potency to give a big impact [32], [33].

\section{CONCLUSION}

Based on the results of the meta-analysis that has been carried out, it can be concluded that (1) the average effect size of the effect of the scientific approach to the improvement of science learning outcomes of elementary schools students by $1.1(\mathrm{SD}=0.537)$ is included in the high effect size categories. The results of the effect size values show that the scientific approach contributes $84 \%-88 \%$ in improving student science learning outcomes in elementary schools; (2) the highest effect size is 2.4 categorized in the high ES category so that it shows that the scientific approach has an effect of $98 \%-99 \%$ on the science learning achievement of elementary school students. Suggestions for researchers and practitioners to use the results of this study to develop a scientific approach to improving student learning outcomes, especially in science learning. Moreover, it can also be used as a result of preliminary research in further research on scientific approaches in science learning.

\section{ACKNOWLEDGMENT}

Acknowledgments are addressed to the Rector of Universitas Slamet Riyadi and the Head of the Center for Research and Community Service at the Universitas Slamet
Riyadi who have provided the opportunity to conduct research and provide funding for the research.

\section{REFERENCES}

[1] M. O. Martin, I. V. S. Mullis, P. Foy, and G. M. Stanco, Results in Science. 2011.

[2] P.-Y. Liou and O. Bulut, "The Effects of Item Format and Cognitive Domain on Students' Science Performance in TIMSS 2011," Res. Sci. Educ., vol. 50, no. 1, pp. 99-121, Feb. 2020, doi: 10.1007/s11165-0179682-7.

[3] A. P. Utomo, E. Narulita, and K. Shimizu, "Diversification of Reasoning Science Test Items of Timss Grade 8 Based on Higher Order Thinking Skills : a Case Study of Indonesian," J. Balt. Sci. Educ., vol. 17, no. 1, pp. 152-161, 2015.

[4] A. Fenanlampir, J. R. Batlolona, and I. Imelda, "The struggle of Indonesian students in the context of TIMSS and Pisa has not ended," Int. J. Civ. Eng. Technol., vol. 10, no. 2, pp. 393-406, 2019.

[5] Khusaini and I. G. N. Darmawan, "An investigation of the factors affecting physics performance of Indonesian students based on TIMSS 2011 dataset," 2020, p. 050007, doi: 10.1063/5.0000607.

[6] J. Mazzeo and M. Von Davier, "Review of the Programme for International Student Assessment (PISA) Test Design: Recommendations for Fostering Stability in Assessment Results," Exec. Summ., pp. 1-45, 2009.

[7] P. Susongko, "The model of science proficiency of Indonesian students in PISA 2015,” J. Phys. Conf. Ser., vol. 1567, p. 042044, Jun. 2020, doi: 10.1088/1742-6596/1567/4/042044.

[8] E. L. Chiappetta and T. R. Koballa, Science instruction in the middle and secondary schools: developing fundamental knowledge and skills 7 (Vol. 105). London: Pearson Education Inc., 2010.

[9] R. R. B. Rahardini, I. G. P. Suryadarma, and I. Wilujeng, "The effect of science learning integrated with local potential to improve science process skills," 2017, p. 080008, doi: 10.1063/1.4995192.

[10] I. Wilujeng, W. S. B. Dwandaru, and R. A. B. A. Rauf, "The Effectiveness of Education for Environmental Sustainable Development to Enhance Environmental Literacy in Science Education: A Case Study of Hydropower," J. Pendidik. IPA Indones., vol. 8, no. 4, Dec. 2019, doi: 10.15294/jpii.v8i4.19948.

[11] S. Suyanto, "The implementation of the scientific approach through $5 \mathrm{~ms}$ of the revised curriculum 2013 in Indonesia," Cakrawala Pendidik., vol. 37, no. 1, pp. 22-29, 2018, doi: 10.21831/cp.v37i1.18719

[12] E. Susantini, U. Faizah, B. Yonata, I. Kurniasari, and Suryanti, "Using instructional video to improve awareness of scientific approach in science classroom," Asia-Pacific Forum Sci. Learn. Teach., vol. 19, no. 1 , pp. 1-22, 2018

[13] M. R. Krogsgaard, J. Brodersen, and J. Comins, "A scientific approach to optimal treatment of cruciate ligament injuries.," Acta Orthop., vol. 82, no. 3, pp. 10-15, 2011, doi: 10.3109/17453674.2011.588864.

[14] A. Suyatna, C. Ertikanto, K. Herlina, and F. A. Pradana, "The effectiveness of interactive e-book quantum phenomena compiled with scientific approach in improving higher order thinking skills," J. Phys. Conf. Ser., vol. 1157, p. 032028, Feb. 2019, doi: 10.1088/17426596/1157/3/032028.

[15] E. Ellizar, H. Hardeli, S. Beltris, and R. Suharni, "Development of Scientific Approach Based on Discovery Learning Module," IOP Conf. Ser. Mater. Sci. Eng., vol. 335, p. 012101, Apr. 2018, doi: 10.1088/1757-899X/335/1/012101.

[16] Wiyanto, S. E. Nugroho, and Hartono, "The Scientific Approach Learning: How prospective science teachers understand about questioning," J. Phys. Conf. Ser., vol. 824, p. 012015, Apr. 2017, doi: 10.1088/1742-6596/824/1/012015.

[17] C. Wieman and S. Gilbert, "Taking a scientific approach to science education, part I-research: Developing expertise requires intense practice that includes doing challenging and relevant tasks, followed by feedback and reflection on one's performance," Microbe, vol. 10, no. 4, pp. 152-156, 2015, doi: 10.1128/microbe.10.152.1.

[18] Suciati, M. N. Ali, C. D. Imaningtyas, A. F. Anggraini, and Z. Dermawan, "The Profile of XI Grade Students' Scientific Thinking Abilities on Scientific Approach Implementation," J. Pendidik. IPA Indones., vol. 7, no. 3, Sep. 2018, doi: 10.15294/jpii.v7i3.15382. 
[19] M. Zaim, "Implementing Scientific Approach to Teach English at Senior High School in Indonesia," Asian Soc. Sci., vol. 13, no. 2, p. 33, 2017, doi: 10.5539/ass.v13n2p33.

[20] M. Nasir, L. R. Nastiti, and H. Yuliani, "Obstacle on The Implementation of The Scientific Approach to The Curriculum 2013: a Case Study of Lesson Study in Palangka Raya City," J. Phys. Conf. Ser., vol. 1511, p. 012108, Apr. 2020, doi: 10.1088/17426596/1511/1/012108.

[21] L. Cohen, L. Manion, and K. Morrison, Research Methods in Education, no. August. 2017.

[22] J. Decoster and H. M. Claypool, "A Meta-Analysis of Priming Effects on Impression Formation Supporting a General Model of Informational Biases," Personal. Soc. Psychol. Rev., vol. 8, no. 1, pp. 2-27, 2004, doi: $10.1207 / \mathrm{s} 15327957 \mathrm{pspr} 0801$.

[23] T. A. Trikalinos, G. Salanti, E. Zintzaras, and J. P. A. Ioannidis, "MetaAnalysis Methods," Adv. Genet., vol. 60, no. 07, pp. 311-334, 2008, doi: 10.1016/S0065-2660(07)00413-0.

[24] L. a Becker, "Effect size ( ES ) - Part I." p. 14, 2000.

[25] J. Cohen, Statistical Power Analysis for the Behavioural Science. 2013.

[26] R. Coe, "What effect size is and why it is important," Http://Www.Leeds.Ac.Uk/Educol/Documents/00002182.Htm, pp. 113, 2011.

[27] N. Shofiyah, I. Afrilia, and F. E. Wulandari, "Scientific Approach and The Effect on Students Scientific Literacy," J. Phys. Conf. Ser., vol. 1594, p. 012015, Jul. 2020, doi: 10.1088/1742-6596/1594/1/012015.

[28] J. A. Jaramillo, "Vygotsky's sociocultural theory and contributions to the development of constructivist curricula," Education, vol. 117, no. 1, pp. 133-141, 1996.

[29] S. Marginson and T. K. A. Dang, "Vygotsky's sociocultural theory in the context of globalization," Asia Pacific J. Educ., vol. 37, no. 1, pp. 116-129, 2017, doi: 10.1080/02188791.2016.1216827.

[30] K. Bati and F. Kaptan, "The effects of science education based on science process skills on scientific problem solving," Elem. Educ. Online, vol. 12, no. 2, pp. 512-527, 2013, doi: 10.17051/io.01022.

[31] P. Turiman, J. Omar, A. M. Daud, and K. Osman, "Fostering the 21st Century Skills through Scientific Literacy and Science Process Skills," Procedia - Soc. Behav. Sci., vol. 59, pp. 110-116, 2012, doi: 10.1016/j.sbspro.2012.09.253.

[32] A. D. Saputro, Irwanto, Sri Atun, and I. Wilujeng, "The impact of problem solving instruction on academic achievement and science process skills among prospective elementary teachers," Elem. Educ. Online, vol. 18, no. 2, pp. 496-507, 2019, doi: 10.17051/ilkonline.2019.561896.

[33] A. Amrianto and L. Lufri, "Effect of Example Non Example Method Implementation in Scientific Approach and Discovery Learning Model on VII Grade Students' Cognitive Competence in Learning Natural Science," J. Phys. Conf. Ser., vol. 1387, p. 012049, Nov. 2019, doi: 10.1088/1742-6596/1387/1/012049. 